\title{
COMPARANDO E INTEGRANDO: ENTRE O CRESCIMENTO ECONÔMICO, A HISTÓRIA GLOBAL E A GRANDE DIVERGÊNCIA
}

Comparing and Integrating: Between Economic Growth, Global History and the Great Divergence 


\title{
RESUMO
}

O artigo discute o método comparativo-integrativo como ferramenta de análise de estudiosos - tais como Kenneth Pomeranz, André Gunder Frank, Jack Goldstone e John M. Hobson - ligados à perspectiva da Grande Divergência. Esses historiadores, chamados de revisionistas, criticam noções que reputam eurocêntricas sobre o crescimento econômico global entre os anos 1400 e 1800, aproximadamente. Com a comparação e a integração, os revisionistas escrutinaram os fatores holísticos que favoreceram o desenvolvimento do capitalismo histórico, apontando uma perspectiva que permite vislumbrar uma história global com amplas integrações no mundo afro-euro-asiático antes do capitalismo globalizante dos séculos XIX e XXI. Como conclusão, pode-se entender que o desenvolvimento do capitalismo histórico a partir do longo século XVI integrou múltiplos espaços do mundo afro-euro-asiático, que se condicionaram mutuamente, num processo sempre crescente de globalização das relações econômicas e de desenvolvimento de amplas redes comerciais.

\section{PALAVRAS-CHAVE}

Comparação. Integração. Eurocentrismo.

\begin{abstract}
The article discusses the comparative-integrative method as a tool of analysis of scholars - such as Kenneth Pomeranz, André Gunder Frank, Jack Goldstone and John M. Hobson - linked to the Great Divergence perspective. These historians, called revisionists, criticize notions that repute Eurocentric about global economic growth between the years 1400 and 1800 approximately. With the comparison and integration, the revisionists scrutinized the holistic factors that favored the development of historical capitalism, pointing out a perspective that allows a glimpse into a global history with wide integration in the Afro-Euro-Asian world before the globalizing capitalism of the $19^{\text {th }}$ and $21^{\text {st }}$ centuries. Concluding, we understand that the development of historical capitalism since the long sixteenth century integrated multiple spaces of the Afro-Euro-Asian world that conditioned each other, in an ever increasing process of globalization of economic relations and development of broad commercial networks.
\end{abstract}

\section{KEYWORDS}

Comparation. Integration. Eurocentrism. 
$\mathbf{U}$ m tema amplo e instigante para as ciências humanas é o debate a respeito da Grande Divergência. Os estudos que procuram entender a ascensão do Ocidente (ou do noroeste europeu, ou da Grã-Bretanha, conforme a perspectiva) retomam, em análises comparativas, explicações que destacam as particularidades da industrialização europeia e o atraso de outras regiões do planeta. Nesse debate, os autores que se alinham na perspectiva do late and lucky (Kenneth Pomeranz à frente) procuram reinterpretar a história afro-euro-asiática redimensionando a importância da Ásia na formação da economia mundial capitalista. Para essa corrente, a divergência entre a China (o grande referencial de comparação) e o Ocidente foi tardia (late) e apareceu de fato na passagem do século XVIII para o XIX. A divergência só seria perceptível a partir da década de 1840 (FRANK, 1998; GOLDSTONE, 2009; HOBSON, 2006; POMERANZ, 2013). Entre os fatores que ensejaram a industrialização da Grã-Bretanha e a posterior ascensão do Ocidente estaria a "sorte geográfica" (lucky, apenas Pomeranz). Minas de carvão próximas a locais de consumo e que se enchiam de água, tornando necessário criar bombas de sucção, estariam entre os fatores que permitiram o impulso industrial britânico. Além desse, Pomeranz aduz outro motivo: o colonialismo terá sido um elemento fundamental para se entender o avanço do noroeste europeu (especialmente da Grã-Bretanha). Em síntese, o Novo Mundo representou um "alívio ecológico" para a Europa, e estes teriam sido os dois pilares que garantiram a ascensão da Grã-Bretanha: o carvão - uma nova fonte de energia e o Novo Mundo. Essa corrente de interpretação, chamada de revisionista (VILLELA, 2009, p. 130), critica o eurocentrismo de autores que veem a ascensão do Ocidente (e da Grã-Bretanha em especial) como endógena, na linha do excepcionalismo europeu. Entre os autores vinculados a esta última linha, estão Eric Jones (1987), com O milagre europeu (1400-1800): contextos, economias e geopolíticas na história da Europa e da Ásia, e David Landes (1998), com A riqueza e a pobreza das nações: por que algumas são tão ricas e outras são tão pobres?.

O debate acerca da Revolução Industrial, do desenvolvimento econômico-tecnológico do "Ocidente" e das razões pelas quais o "Oriente" não avançou rumo à industrialização é bastante extenso e profícuo. Apresentamos aqui uma breve perspectiva de duas correntes radicalmente opostas (a do excepcionalismo europeu, exemplificada com as obras de David Landes e Eric Jones, e a dos revisionistas, representada por autores como André Gunder Frank e Kenneth Pomeranz, entre outros).

Sem pretender esgotar as linhas interpretativas, seria possível levantar mais três correntes explicativas para entender o crescimento econômico do mundo pré-industrial ou, se se preferir um marco cronológico um pouco mais preciso, o desenvolvimento do capitalismo histórico antes do século XIX. A primeira delas pode ser denominada perspectiva institucionalista-estatal. Apesar de os campos de abordagem dessa corrente serem muito diferentes, é preciso sublinhar que em todos o Estado aparece como um dos elementos essenciais para se entender o crescimento econômico. Acadêmicos de diferentes matizes como Douglass C. North (1990), Fernand Braudel (1987), Giovanni Arrighi (2012), John Brewer (1989) e Peer Vries (2015) poderiam ser incluídos porque, entre outros fatores, todos salientam que o Estado foi essencial para promover crescimento econômico na Idade Moderna. Para Vries, o papel do Estado no crescimento econômico da era moderna é direto, e não contingencial. Classificando como "capitalismo mercantilista" a ação estatal de criação de monopólios e o uso da violência na prática do comércio, Vries discute a "mão visível" do Estado, seu 
papel intervencionista, o mercantilismo, a importância da guerra e da violência e o militarismo como fatores do crescimento econômico. O Estado fiscal-militar britânico (e, em menor escala, de outros países do norte europeu) foi responsável por acentuar a divergência. Isso num momento anterior à industrialização efetiva, que começou a se acentuar na passagem do século XVIII para o XIX (VRIES, 2015, p. 301-302). As ideias de North, Braudel, Arrighi e Brewer (com seu conceito de Estado fiscal-militar) a respeito do Estado no desenvolvimento do capitalismo histórico foram o suporte para o trabalho de Vries.

Outra linha interpretativa seria a do debate sobre a transição do feudalismo para o capitalismo, capitaneado por Maurice Dobb e Paul Sweezy (HILTON et al., 1977), e, por fim, a perspectiva do sistema mundial moderno, encabeçada por Immanuel Wallerstein (1991), segundo a qual o funcionamento sistêmico da economia mundial capitalista aconteceria por meio de cadeias de mercadorias que engendrariam relações centro-periferia com trocas desiguais e transferência de excedentes da periferia para o centro. Segundo os revisionistas, todas essas linhas interpretativas - excepcionalismo europeu, institucionalista/estatal, transição do feudalismo para o capitalismo e sistema mundial moderno - se caracterizam por um viés eurocêntrico que desvirtua o entendimento do crescimento econômico em diversas partes do mundo no período pré-industrial e impede a real compreensão do crescimento econômico mundial. O "mundo real" do período pré-industrial teria sido marcado por inter-relações e interconexões globais que muitas vezes foram negligenciadas ou simplesmente relegadas.

Isto posto, o objetivo deste artigo é investigar os pressupostos do método comparativo-integrativo como uma ferramenta de análise dos revisionistas para criticar as perspectivas que eles classificam como eurocêntricas. O artigo não pretende ser uma adesão pueril às teses basilares dos autores ditos revisionistas, já devidamente criticadas por diversos estudiosos (BRYANT, 2006; VILLELA, 2009; VRIES, 2001, 2015), mas discutir aquilo que pode ser útil para uma análise global da história ou seja, o método comparativo-integrativo como ferramenta crítica das perspectivas eurocêntricas de compreensão do desenvolvimento do capitalismo histórico. Os teóricos que se propõem a analisar o campo de estudo da história comparada se esquecem de incluir os autores revisionistas que se detiveram nas razões da Grande Divergência. Sendo assim, procuramos nos concentrar num rol daqueles que usaram de alguma maneira o método comparativo-integrativo para criticar os que viram na Europa, no Ocidente ou, mais especificamente, na Inglaterra/Grã-Bretanha fatores morais, econômicos, sociais, políticos e/ou institucionais para o crescimento econômico e que levaram ao desenvolvimento industrial e, por consequência, a uma elevação do padrão de vida, dos salários, da tecnologia etc.

Em suma, o artigo se concentra nos autores que de algum modo criticaram uma narrativa centrada exclusivamente na Europa. Como se vê, muitos autores construíram uma explicação eurocêntrica para entender o fenômeno do desenvolvimento do capitalismo histórico, e, como afirmou John M. Hobson (2006, p. 19), a tese eurocêntrica desconsidera que Ocidente e Oriente estiveram interligados consistente e constantemente desde a globalização que se construiu a partir de cerca de 500 d.C. Além disso, as quatro linhas interpretativas criticadas pelos revisionistas geralmente focalizam as causas internas do expansionismo europeu e do desenvolvimento do capitalismo, esquecendo-se dos fatores exógenos que interferiram no crescimento europeu. 


\section{COMPARAR E INTEGRAR: RECURSOS EXPLICATIVOS PARA ENTENDER O CRESCIMENTO ECONÔMICO GLOBAL (C. 1400-C. 1800-1850)}

Nos últimos anos, introduziram-se no debate acadêmico perguntas como "qual o motivo para a ascensão do Ocidente?", "por que a Revolução Industrial ocorreu na Grã-Bretanha?", "qual a razão para a riqueza e a pobreza das nações?" ou "como os países ricos enriqueceram de fato?", conforme o título do capítulo I do livro do economista sul-coreano Ha-Joon Chang (2004, p. 11). Comparar e integrar é a metodologia usada pelos revisionistas para responder a essas questões e debater teses que classificam como eurocêntricas.

Considerando os propósitos deste artigo e tendo como base o pensamento geral dos revisionistas, o eurocentrismo pode ser definido como uma escrita da história mundial que entende a difusão e a expansão do capitalismo histórico a partir do "Ocidente", atingindo, em escala sempre crescente, o mundo inteiro, tornando periféricas ao centro europeu diversas regiões e civilizações ao redor do planeta. Nos termos de Marcel van der Linden (2013, p. 11):

[...] [o eurocentrismo] pode ser definido como o ordenamento mental do mundo a partir da perspectiva da região do Atlântico Norte - o período 'moderno' [seria] visto como tendo começado na Europa e na América do Norte, ampliando-se gradualmente para o resto do mundo, e a temporalidade da 'região central' determina[ria] a periodização dos deslocamentos ocorridos nas demais regiões.

Para Alexander Anievas e Kerem Nisancioglu (2015, p. 4-5), o eurocentrismo caracteriza-se por três hipóteses inter-relacionadas. A primeira, que os autores chamam de internalismo metodológico, concebe a ascensão do Ocidente como endógena e autônoma. Nesses termos, a Europa seria o centro da História e, portanto, base para a expansão da economia mundial. A segunda hipótese procura posicionar a sociedade e a cultura europeias como superiores às demais, promovendo uma separação radical entre "o Ocidente e o Resto" ("the West and the Rest"). A essa perspectiva, os autores denominam prioridade histórica. Por fim, um terceiro elemento, o desenvolvimentismo linear, concebe as mudanças sociais (da tradição para a modernidade, do feudalismo para o capitalismo etc.) como processos universais pelos quais todas as sociedades devem passar para alcançar os níveis ocidentais de desenvolvimento. Entre muitas possibilidades, é certo que os autores revisionistas concordariam com essa conceituação, e todos eles procuram romper com a narrativa eurocêntrica.

Kenneth Pomeranz (2013) talvez seja o autor mais célebre do debate sobre a ascensão do Ocidente e o "atraso" do Oriente. Em seu A grande divergência: a China, a Europa e a construção da economia mundial moderna, adota a metodologia comparativo-integrativa. Peer Vries (2001, p. 401-402), um dos críticos das teses dos revisionistas (e, em especial, do livro de Pomeranz), concorda que essa metodologia é eficaz e que só pela comparação se poderia entender a ascensão do Ocidente. Para Pomeranz (2013, p. 495), o método comparativo não é apenas um exercício para buscar as diferenças e semelhanças entre regiões como a China e a Grã-Bretanha, 
por exemplo, ${ }^{1}$ mas implica "reconhecer a importância das conexões preexistentes na criação dessas diferenças". "Conexões preexistentes" construídas pelos próprios países/regiões em dois âmbitos: (i) com regiões externas, pelo comércio de longa distância, e (ii) entre os próprios países que integram determinado sistema interestatal emfuncionamento (e que, ressalte-se, não está isolado de outros sistemas interestatais). O autor procura combinar três elementos para explicar a divergência: análise comparativa, contingências locais e uma abordagem integrativa ou global (POMERANZ, 2013, p. 17). Considerados uma "abordagem comparativa e integrativa", esses três elementos não procuram uma "diferença europeia" ou algo exclusivo da cultura ou da história da Europa, na linha da excepcionalidade europeia, e tampouco analisar mundos separados como unidades de comparação. A abordagem é comparativa não pela procura de diferenças que distingam a Europa das outras regiões do planeta. Em outros termos, a comparação não concebe um sistema mundial eurocêntrico, mas sim um "mundo policêntrico sem nenhum centro dominante", segundo Pomeranz (2013, p. 18). Para usarmos uma denominação comum aos programas de História das universidades, essa seria a característica da História Moderna. A comparação deveria ser igualmente integrativa pela análise das conjunturas globais de um mundo concebido como policêntrico e que vincularia as unidades existentes no período préindustrial direcionando internamente o desenvolvimento de cada uma delas. Tratando do fluxo de metais do Novo Mundo para diversos pontos da economia mundial, Pomeranz (2013, p. 456) escreve que "[...] foi a intersecção das dinâmicas europeias com outras dinâmicas regionais que determinou a extensão e a natureza dos fluxos dos metais: a economia mundial permaneceu policêntrica e as forças emanadas de outros lugares podiam moldá-la tanto como as forças emanadas da Europa”.

Em suma, a comparação não é uma ferramenta para procurar uma diferença europeia, um milagre europeu ou um milagre britânico, mas para analisar conjunturas globais que moldaram as unidades de análise e as direcionaram para um caminho ou outro. Esse método implica olhar "duas partes de um todo" e ver como "a posição e a função de cada uma no sistema moldou" a natureza dessas unidades de análise (POMERANZ, 2013, p. 26).

O método comparativo exige que o estudioso faça recortes. Do ponto de vista de Pomeranz, não seria necessariamente correto comparar "China" com "GrãBretanha" ou "Índia" com "Grã-Bretanha". É importante perguntar "que China?", "que Grã-Bretanha?”, "que Índia?”. Por exemplo, por volta de 1750, a diversidade interna da China conduziu à preeminência da região do baixo langtsé (com 31-37 milhões de habitantes) e, numa segunda ordem de importância, o sudeste da China, a região de Lingnan, que englobava as províncias de Guangdong, Guangxi e Hainan. Assim, para identificar contingências e conjunturas, valeria a pena prestar atenção em núcleos específicos dentro das unidades maiores. A comparação entre esses núcleos deveria ser verdadeiramente recíproca, ou seja:

[...] procurar as ausências, os acasos e os obstáculos que desviaram a Inglaterra de um caminho que a poderia ter tornado

\footnotetext{
${ }_{1}^{1}$ Como contraponto a Pomeranz e dentro do campo revisionista, vale a pena mencionar o trabalho de Jack Goldstone (2009, p. 15), que adota o método comparativo para procurar diferenças entre o "Oriente" e o "Ocidente" e identificar os fatores que permitiram a ascensão deste último.
} 
mais parecida com o delta do langtsé ou com o Guzerate [região a oeste da atual Índia, próxima da fronteira do Paquistão], juntamente com o exercício mais habitual de procurar bloqueios que tenham impedido as zonas não europeias de reproduzir vias europeias implicitamente normalizadas (POMERANZ, 2013, p. 23).

Portanto, Pomeranz (2013, p. 24, 27) usa o método comparativo para enfatizar as conjunturas e influências recíprocas num mundo pré-industrial concebido como policêntrico:

Isso pode fazer-se, em parte, olhando para ambos os lados da comparação como 'desvios' quando vistos pelas expectativas do outro, em vez de deixar sempre uma parte como a norma. [...] A nossa percepção de um sistema interativo do qual uma parte beneficiou-se mais do que as outras não justifica que se chame a essa parte o 'centro' nem que se parta do princípio de que ela é a moldadora não moldada de todo o resto. Pelo contrário, veremos vetores de influência deslocando-se em várias direções.

Eis aí uma crítica à noção de centro-periferia dos teóricos do sistema-mundo, Immanuel Wallerstein à frente. A perspectiva wallersteiniana desvirtuaria a compreensão acerca do desenvolvimento europeu, ou britânico, enfatizando a dimensão "moldadora" desse "centro europeu/britânico" e colocando em segundo plano - ou simplesmente desconsiderando - as contingências mundiais que "moldaram" o crescimento do referido "centro".

Como anunciamos na introdução, os estudiosos ditos revisionistas costumam se opor, até com certa veemência, aos pilares que fundamentam o conceito de sistema mundial moderno de Wallerstein. Em seu livro, Pomeranz sugere que as colônias foram importantes não como resultado dos ganhos que elas proveram à Europa em decorrência da exploração, mas devido à existência do que o autor da Escola da Califórnia ${ }^{2}$ chamou de "acres fantasmas", que deram aos países europeus um alívio ecológico imenso. Para o autor, o Novo Mundo salvou a Europa de uma crise ecológica e

[...] revelou-se vital - não tanto pela acumulação de capital (ao contrário do que argumentam alguns especialistas), mas porque os seus recursos ajudaram a Europa a transitar de uma via de desenvolvimento ecologicamente limitada e exigente em mão de obra (que partilhava com a China e o Japão) para uma via mais transformadora que utilizou quantidades prodigiosas de energia e terra (POMERANZ, 2013, p. 194).

Segundo seu ponto de vista, essa "via de desenvolvimento ecologicamente limitada" foi o entrave da China rumo à industrialização. Diferentemente da Europa, que se beneficiara da periferia do continente americano, a China não contou com

\footnotetext{
${ }^{2}$ A denominação "Escola da Califórnia" foi criada por um de seus expoentes, Jack Goldstone, para designar estudiosos que, baseados em diversas universidades da Califórnia na década de 1990, começaram a questionar as explicações eurocêntricas para o crescimento econômico global do período compreendido entre 1400 e 1800, aproximadamente (VILLELA, 2009, p. 133).
} 
nenhum alívio ecológico. Malgrado as críticas que sofre Pomeranz, o que se ressalta aqui não é a discussão histórica sobre a crise ecológica na China e na Europa, o papel de suas respectivas periferias ou a apreciação do autor sobre as teses de Wallerstein, mas sua proposta de se pensar uma perspectiva comparativa-integrativa do mundo pré-industrial. Tal método pode ajudar a redimensionar a perspectiva eurocêntrica que vem dominando muitos estudos sobre o crescimento econômico europeu e global. Contudo, é certo que, muitas vezes, esse método proposto por Pomeranz parece não se encaixar com sua análise histórica pela ausência de processo histórico e pela comparação estática, formal e, portanto, não integrativa, entre as unidades de análise. Entretanto, o estudo crítico desse último ponto foge ao escopo deste artigo.

André Gunder Frank é outro autor que se opõe veementemente aos pilares que fundamentam a tese eurocêntrica. Para ele, as categorias hegemonia, centro/periferia, modo de produção asiático, pré-capitalismo e sociedade não capitalista, entre outras, não têm bases cientificas. Em seus duros termos:

[...] estas categorias são de resto algo pior que inúteis, cientificamente falando, pois seus simples usos desviam-se de qualquer análise verdadeira sobre a realidade do mundo, assim como da compreensão deste. A única solução é cortar de todo o nó górdio e livrarmo-nos de todas estas inúteis categorias eurocêntricas que só levam a debates esotéricos que nos cegam ante os processos históricos reais (FRANK, 1998, p. 336).

Isso porque, para o autor, o mundo de cerca de 1400-1800 deve ser entendido com base em outros paradigmas que não os da literatura eurocêntrica. Para Gunder Frank (1998, p. 117), o mundo antes de 1800-1840 era marcadamente sinocêntrico. ${ }^{3}$

A crítica a um centro europeu que moldou o mundo por uma expansão em bases, digamos, capitalistas é o cerne do trabalho de outro autor revisionista: John M. Hobson. Seu livro The Eastern Origins of Western Civilization faz uma análise muito mais integrativa que comparativa, ainda que a comparação não esteja completamente ausente. Questionando as teses ditas eurocêntricas sobre as origens do capitalismo histórico e da Revolução Industrial, o autor entende que o Oriente e o Ocidente não são duas entidades opostas, mas que ambas estavam ligadas fundamentalmente por "laços de globalização" desde pelo menos 500 d.C. Assim, à ideia de Ocidente autônomo e com desenvolvimento imanente, na linha da excepcionalidade europeia, o autor opõe o conceito de Ocidente oriental (HOBSON, 2006, p. 19). De modo que Hobson procura desenvolver duas teses: a primeira, de que as civilizações do Oriente foram sujeitos e agentes da globalização, e de que o "Ocidente" assimilou suas "carteiras de recursos" por meio da globalização oriental do período 500-1800. A outra é a de que a identidade europeia e a agência europeia foram elementos fundamentais para a apropriação dos recursos orientais. Quando se considera que o Ocidente só conseguiu avançar porque se apropriou da carteira de recursos do Oriente, conclui-se que a tese da imanência para o desenvolvimento europeu é completamente descabida. Esse duplo processo - transmissão e assimilação das carteiras de recursos orientais por meio da

\footnotetext{
${ }^{3}$ Mais adiante, veremos que Gunder Frank transita entre as concepções de um mundo sinocêntrico e de um mundo policêntrico, parecendo aderir mais à segunda perspectiva.
} 
globalização oriental e apropriação dos recursos do Oriente por meio do imperialismo - impulsionou o Ocidente rumo ao crescimento econômico e à industrialização. Assim, para Hobson, o Oriente e o Ocidente não devem ser tomados como entidades distintas e antitéticas. São complementares e permaneceram (e ainda permanecem) unidos numa rede global de comércio e trocas diversas pelo menos desde o ano 500.

Ao não conceber o Oriente e o Ocidente como unidades distintas e antitéticas, Hobson desenvolve a noção de globalização oriental. Para o autor, não houve expansão do mercado mundial impulsionada pelos europeus, mas incorporação dos europeus a uma globalização preexistente, o que, por si só, subverteria completamente a tese de Wallerstein. Segundo seu ponto de vista, as teses eurocêntricas desconsideram o que existia em várias regiões da Ásia no período da globalização oriental; por exemplo, (i) o alto grau de produtividade agrícola de várias civilizações asiáticas; (ii) os fluxos de moeda; (iii) os sistemas financeiros existentes; (iv) as instituições racionais que funcionavam para garantir a confiabilidade das transações comerciais; (v) a contabilidade; (vi) a prática da commenda ${ }^{4}$ entre os muçulmanos; (vii) os governos que promoveram a proteção ao comércio (ver, por exemplo, o Japão Tokugawa); (viii) a produção de ferro e aço em larga escala e as tecnologias usadas para aumentar a produção; (ix) o aumento de produtividade com o uso de novas técnicas agrícolas; (x) a ética comercial presente no Corão; (xi) o desenvolvimento de um capitalismo financeiro em diversas partes da Ásia etc. Ou seja, Hobson (2006, p. 96) entende que "a distribuição do poder econômico no mundo sob a globalização oriental foi 'policêntrica', e todos os países e regiões, China, Índia, Oriente Médio e norte da África, Sudeste da Ásia e Japão, desempenharam papéis significativos".

Com Hobson, temos a metodologia integrativa para entender um mundo pré-industrial distante das noções eurocêntricas. Essa perspectiva afasta-se do entendimento de uma Europa (ou noroeste europeu, ou Ocidente, ou, se se preferir, a Grã-Bretanha) como polo hegemônico de expansão do capitalismo histórico. Seu estudo aponta as "origens orientais" (asiáticas) da revolução financeira das cidades italianas na transição da "Idade Média para a Moderna", da "revolução náutica" europeia e da revolução "energética" e "protoindustrial" ocorrida no continente europeu (HOBSON, 2006, p 116-133). Portanto, a integração proposta por Hobson conduz à compreensão de que o mundo afro-euro-asiático desenvolveu ligações fundamentais e constantes que fortaleceram os "laços de globalização" no período anterior a 1800.

Outro ponto importante e que perpassa o trabalho de muitos revisionistas são os dados populacionais. No caso específico da China, Hobson faz uma associação entre urbanização, cidades populosas e desenvolvimento do comércio desde o período da dinastia Sung (séculos X-XIII) para concluir que a urbanização nesse momento histórico foi mais pronunciada na China do que na Europa e enfatizar que a China tinha as cidades mais populosas do mundo (HOBSON, 2006, p. 56). Para os revisionistas, esse é um indicador que permite vislumbrar a dimensão da Ásia diante da Europa no mundo pré-industrial. A despeito das análises que se possam fazer com dados demográficos (expectativa de vida, taxas de crescimento populacional,

\footnotetext{
4 Segundo John M. Hobson (2006, p. 119-120), a commenda, atribuída aos italianos, que a teriam inventado no século XI, seria de fato usada no Oriente Médio pelos muçulmanos antes dessa época: tratava-se de um "acordo contratual em que um investidor financiava a viagem de um mercador". A commenda foi fundamental para garantir segurança ao comércio internacional.
} 
estatura da população, padrões de casamento, crescimento populacional que gera problemas ecológicos, índices de natalidade e mortalidade etc.), Jack Goldstone (2009, p. 83) entende que "a presença de grandes cidades também sugere extensas redes de comércio para atender às necessidades das populações urbanas e vastos sistemas de transportes para trazer mercadorias para os mercados urbanos". Para Gunder Frank (1998, p. 299-300), o rápido aumento populacional na Ásia entre 14001800 impediu um avanço tecnológico significativo, que teria criado tecnologias que utilizassem menos mão de obra. Ao contrário, com população menor que a da Ásia e, portanto, mão de obra mais cara, a Europa conheceu um processo histórico de investimentos tecnológicos para substituir essa mão de obra.

Já Pomeranz afirma que o crescimento populacional num período posterior ao analisado por Frank, entre 1750 e 1850, foi intenso na Grã-Bretanha e na China, mas cada qual adotou soluções econômicas diferentes para responder a isso. Na China, a produção de cereais acompanhou o crescimento populacional, e essa produção ocupou cada vez mais o espaço de culturas comercializáveis. Na Grã-Bretanha, por outro lado, açúcar, algodão, café e tabaco foram produzidos nos espaços coloniais, o que não pressionou a oferta de cereais. Contudo, dado que a população britânica disparou, esse abastecimento interno de cereais também se tornou insuficiente, exigindo soluções cada vez mais prementes, como o uso de fertilizantes mais potentes oriundos de espaços periféricos. Pomeranz (2013, p. 366) enfatiza as consequências ecológicas do aumento populacional nesses dois espaços, gerando pressão sobre os recursos. Para o autor, sem a dupla benesse do carvão e das colônias (ou das importações), a Grã-Bretanha teria enfrentado "um impasse ecológico sem solução interna aparente". Em suma, Pomeranz discute a pressão ecológica que o aumento populacional exerceu no mundo pré-industrial, fortemente influenciado pelas prerrogativas malthusianas. Essa pressão ecológica gerou mudanças climáticas, problemas ambientais e soluções econômicas diferenciadas tanto na Europa quanto na China. Para esses autores, as cidades mais populosas do mundo encontravam-se na Ásia até pelo menos 1750. O turning point aconteceu a partir da segunda metade do século XVIII, elevando significativamente os números populacionais das cidades europeias. Independentemente das análises feitas por esses autores, os dados populacionais das maiores cidades do mundo permitem redimensionar a importância da Ásia no crescimento econômico global no período anterior a 1800, bem como perceber o impacto gigantesco da Revolução Industrial na passagem do século XVIII para o XIX.

Por fim, André Gunder Frank, já mencionado como um ácido crítico de conceitos da teoria eurocêntrica, transita (às vezes de modo impreciso) entre as noções de sinocentrismo e policentrismo para entender o crescimento econômico no mundo pré-industrial (grosso modo, anterior a 1800). Sua crítica à teoria social eurocêntrica propõe como alternativa uma perspectiva holística da economia mundial. Esse holismo procura analisar o mundo para além das lentes ocidentais e de seus excepcionalismos, e pressupõe um mundo marcado por realidades diferentes, mas não necessariamente separadas. Abordar a história global holisticamente significa conceber um sistema mundial ecumênico, com partes diferentes mas integradas, num mercado mundial com uma rede mercantil afro-euro-asiática. Gunder Frank (1998, p. 52) propõe o comparativismo histórico e o método integrativo, subscreve o conceito de prolífica multicentralidade para entender a história do capitalismo anterior a 1800 e o associa à sua perspectiva holística. A integração econômica caracteriza a história 
afro-euro-asiática e não pode ser ignorada por um viés eurocêntrico que ilumina mais o "centro" europeu, submetendo as chamadas "periferias" a uma posição subalterna e entendendo-as como localidades/civilizações passivas frente à força avassaladora do expansionismo capitalista da Europa (FRANK, 1998, p. 26-34). Mais uma vez, a tese de Frank aponta para a concepção de que o Oriente e o Ocidente não devem ser vistos como "entidades" antitéticas.

Para Gunder Frank, grande parte dos cientistas sociais tem um viés marcadamente eurocêntrico. A influência desse entendimento seria tão poderosa que fundamentaria a base explicativa para os estudantes de educação básica. Trata-se, portanto, da presença marcante de uma ideologia eurocêntrica. Contrariamente, um entendimento holístico da história mundial, considerando a existência de um mercado mundial com uma rede mercantil afro-euro-asiática em funcionamento (algo diferente da concepção wallersteiniana de expansão do mercado mundial a partir da Europa, por exemplo), estaria mais próximo da realidade. Essa abordagem permite conceber o crescimento econômico dentro de uma perspectiva global que não partiria da Europa. Ou seja, para Gunder Frank, a teoria social eurocêntrica não é holística nem se caracteriza por uma dimensão verdadeiramente global. Sua crítica é direta: não é necessária uma terminologia global, mas sim uma teoria e uma análise global - ou, em outros termos, trata-se de conceber um sistema mundial ecumênico, marcado pela "unidade na diversidade" (FRANK, 1998, p. 338). Para Frank, a unidade sistêmica do mundo pré-industrial como ferramenta heurística ajuda a entender a diversidade desse mesmo mundo e a posição de suas várias partes nas redes de comércio mundial.

Como se viu, o revisionismo se posiciona contra as chamadas teses eurocêntricas. Nessa perspectiva, não tem sentido conceber uma transição do feudalismo para o capitalismo de base europeizante, nem um crescimento endógeno europeu desvinculado das interconexões afro-euro-asiáticas, muito menos um sistema mundial expansivo que parte da Europa para abarcar o mundo.

\section{CONSIDERAÇÕES FINAIS}

Em um artigo em que discute (e critica) os revisionistas, André Villela (2009) conclui que "as bases empíricas e metodológicas" dessa corrente de estudo "são vulneráveis". No que tange às teses centrais do livro de Pomeranz - quais sejam, a de um mundo com "incríveis semelhanças" no período anterior a 1800, a da sorte geográfica britânica de dispor de minas de carvão e ao papel de alívio ecológico proporcionado pelo Novo Mundo (ghost acreage) -, parece que Villela tem razão. Em outros termos, a base empírica de Pomeranz é polêmica e rejeitada por diversos estudiosos. Contudo, no que se refere à metodologia tal como trabalhada neste artigo, e considerando a perspectiva global da história, os autores revisionistas analisados aqui podem ser úteis para pensarmos um mundo moderno policêntrico, pautado em redes amplas de comércio, definindo o rumo de cada parte no contexto mais geral de funcionamento dos espaços-de-fluxos do comércio mundial. ${ }^{5}$

Os estudiosos revisionistas que procuram apresentar uma perspectiva não eurocêntrica do desenvolvimento do capitalismo histórico dão preferência ao método

\footnotetext{
${ }^{5} \mathrm{O}$ conceito de "espaços-de-fluxos" como um dos componentes do funcionamento econômico do capitalismo em escala mundial foi desenvolvido e trabalhado por Giovanni Arrighi (2012, p. 81).
} 
comparativo e integrativo. Eles propõem que se evite a comparação formal, tal como explicada pelo historiador Dale Tomich (2011, p. 153), apesar de Pomeranz, um dos grandes expoentes dessa linha interpretativa, nem sempre conseguir escapar desse último tipo de comparação.

De qualquer modo, os revisionistas vêm promovendo um rico debate a respeito de suas teses essenciais - entre elas os fatores holísticos que possibilitaram o desenvolvimento do capitalismo histórico -, apontando uma perspectiva que permite vislumbrar uma história global e não eurocêntrica anterior ao capitalismo globalizante dos séculos XIX-XXI. Além disso, os métodos propostos por esses autores ensejam uma compreensão mais dinâmica (menos estanque) do desenvolvimento do capitalismo histórico, mirando o mundo afro-euro-asiático a partir do longo século XVI (ou, como se viu no caso de John M. Hobson, a partir da globalização oriental, que germinou depois do ano 500 d.C.) e procurando entender os múltiplos espaços que se condicionaram mutuamente, num processo sempre crescente de globalização das relações econômicas. Em linhas gerais, esses autores reconhecem a ruptura provocada pela Revolução Industrial, mas destacam que a divergência que se passa a acentuar então só ocorreu por uma dinâmica do processo histórico global vinculado ao próprio funcionamento do mundo afro-euro-asiático. Nesse quadro, destaca-se a pesquisa de John M. Hobson, que trabalhou em perspectiva holística as amplas integrações existentes no mundo afro-euro-asiático. Para ele, a partir de cerca de 500 d.C., já era perceptível que Oriente e Ocidente não eram unidades distintas e antitéticas, mas sim regiões distantes e complementares que desenvolveram inúmeras redes globais de comércio e interação.

Os autores aqui analisados, inseridos no debate a respeito da Grande Divergência, procuraram promover um "alargamento espacial" como recurso interpretativo para entender uma história não eurocêntrica. Assim, a comparação e a integração seriam a base para uma nova teoria, em que o "internacional" estaria presente de modo orgânico, revelando e promovendo interações e crescimento econômico combinado e desigual. Essa organicidade pressupõe (a) uma formulação teórica que permite entender como as sociedades interagem e como mudam, e as relações entre os processos históricos de desenvolvimento num mundo afro-euro-asiático integrado, e (b) o entendimento de que o "Oriente" e a "África" não podem ser vistos como entidades "externas" e "contingentes", reforçando os fatores internos que promoveram o crescimento econômico europeu (ANIEVAS; NISANCIOGLU, 2015, p. 11, 44).

\section{REFERÊNCIAS}

ANIEVAS, Alexander; NISANCIOGLU, Kerem. How the West Came to Rule. London: Pluto, 2015.

ARRIGHI, Giovanni. O longo século XX: dinheiro, poder e as origens do nosso tempo. Rio de Janeiro: Contraponto, 2012.

BREWER, John. The Sinews of Power: War and the English State, 1688-1783. London: Unwin Hyman, 1989.

BRAUDEL, Fernand. A dinâmica do capitalismo. Rio de Janeiro: Rocco, 1987. 
BRYANT, Joseph M. The West and the Rest Revisited: debating capitalist origins, European Colonialism, and the Advent of Modernity. Canadian Journal of Sociology, Edmonton, v. 31, n. 4, p. 403-444, 2006.

CHANDLER, Tertius; FOX, Gerald. 3000 Years of Urban Growth. New York: Academic Press, 1974.

CHANG, Ha-Joon. Chutando a escada: a estratégia do desenvolvimento em perspectiva histórica. São Paulo: Editora da Unesp, 2004.

FRANK, André Gunder. ReOrient: Global Economy in the Asian Age. Berkeley: University of California Press, 1998.

GOLDSTONE, Jack. Why Europe? The Rise of the West in the World History, 15001850. New York: McGraw-Hill, 2009.

HILTON, Rodney; DOBB, Maurice; SWEEZY, Paul; TAKAHASHI, Kohachiro; LEFEBVRE, Georges; HILL, Christopher; PROCACCI, Giuliano; HOBSBAUM, Eric; MERRINGTON, John. A transição do feudalismo para o capitalismo: um debate. São Paulo: Paz e Terra, 1977.

HOBSON, John M. Los orígenes orientales de la civilización de Occidente. Barcelona: Crítica, 2006.

JONES, Eric. O milagre europeu (1400-1800): contextos, economias e geopolíticas na história da Europa e da Ásia. Lisboa: Gradiva, 1987.

LANDES, David. A riqueza e a pobreza das nações: por que algumas são tão ricas e outras são tão pobres? Rio de Janeiro: Campus, 1998.

LINDEN, Marcel van der. Trabalhadores do mundo: ensaios para uma história global do trabalho. Campinas: Editora da Unicamp, 2013.

NORTH, Douglass C. Institutions, Institutional Change, and Economic Performance. Cambridge: Cambridge University Press, 1990.

POMERANZ, Kenneth. A grande divergência: a China, a Europa e a construção da economia mundial moderna. Lisboa: Edições 70, 2013.

SPENCE, Jonathan D. Em busca da China moderna: quatro séculos de história. São Paulo: Companhia das Letras, 1995.

TOMICH, Dale. Pequenas ilhas e grandes comparações. In: TOMICH, Dale. Pelo prisma da escravidão: trabalho, capital e economia mundial. São Paulo: Editora da Edusp, 2011. p. 151-168. 
VILLELA, André. As origens da grande divergência: uma sistematização do debate acerca da ascensão do Ocidente. História Econômica \& História das Empresas, v. XII, n. 2, p. 129-168, 2009.

VRIES, Peer. State, Economy, and the Great Divergence: Great Britain and China, 1680's-1850's. London: Bloomsbury, 2015.

VRIES, Peer. Are Coal and Colonies Really Crucial? Kenneth Pomeranz and the Great Divergence. Journal of World History, Hawaii, v. 12, n. 2, p. 407-446, 2001.

WALLERSTEIN, Immanuel. El moderno sistema mundial: la agricultura capitalista y los orígenes de la economía-mundo europea en el siglo XVI. Madrid: Siglo XXI, 1991.

\section{NOTAS}

\section{AUTORIA}

Marco Aurélio dos Santos. Doutor. Pesquisador, Universidade de São Paulo, Faculdade de Filosofia Letras e Ciências Humanas, Laboratório de Estudos sobre o Brasil e o Sistema Mundial, São Paulo, SP, Brasil.

\section{ENDEREÇO PARA CORRESPONDÊNCIA}

Alameda dos Guatás, 90, apt. 64, 04053-040, São Paulo, SP, Brasil.

\section{ORIGEM DO ARTIGO}

O artigo faz parte de pesquisa de pós-doutorado intitulada "A China e o tráfico de coolies para as Américas no século XIX" realizada entre julho de 2016 e julho de 2018 no Programa de Pós-doutorado do Departamento de História da Faculdade de Filosofia, Letras e Ciências Humanas da Universidade de São Paulo.

\section{AGRADECIMENTOS}

Agradeço aos pareceristas que indicaram mudanças no original. Também gostaria de agradecer a leitura crítica feita por Alain el Youssef.

\section{FINANCIAMENTO}

Não se aplica.

\section{APROVAÇÃO DE COMITÊ DE ÉTICA EM PESQUISA \\ Não se aplica.}

\section{CONFLITO DE INTERESSES}

Não houve conflito de interesses.

\section{LICENÇA DE USO}

Este artigo está licenciado sob a Licença Creative Commons CC-BY. Com essa licença você pode compartilhar, adaptar e criar para qualquer fim, desde que atribua a autoria da obra.

\section{PUBLISHER}

Universidade Federal de Santa Catarina. Programa de Pós-Graduação em História. Portal de Periódicos UFSC. As ideias expressadas neste artigo são de responsabilidade de seus autores, não representando, necessariamente, a opinião dos editores ou da universidade. 


\section{EDITORES}

Flávia Florentino Varella (Editora-chefe)

Tiago Kramer de Oliveira

Waldomiro Lourenço da Silva Júnior

\section{HISTÓRICO}

Recebido em: 02 de agosto de 2019

Aprovado em: 23 de janeiro de 2020

Como citar: SANTOS, Marco Aurélio dos. Comparando e integrando: entre o crescimento econômico, a história global e a grande divergência. Esboços, Florianópolis, v. 27, n. 44, p. 115-129, jan./abr. 2020. 